Journal of Telenursing (JOTING)

Volume 2, Nomor 1, Juni 2020

e-ISSN: 2684-8988

p-ISSN: 2684-8996

DOI: https://doi.org/10.31539/joting.v2i1.1126

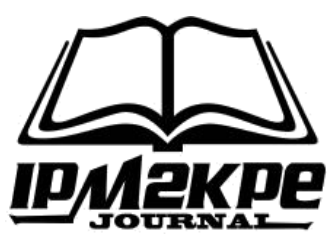

\title{
SENAM LANSIA MENURUNKAN TEKANAN DARAH PADA LANSIA
}

\author{
Andry Sartika ${ }^{1}$, Betrianita ${ }^{2}$, Juli Andri ${ }^{3}$, Padila $^{4}$, Ade Vio Nugrah ${ }^{5}$, \\ Universitas Muhammadiyah Bengkulu ${ }^{1,2,3,4,5}$ \\ andryrover@gmail.com ${ }^{1}$
}

\begin{abstract}
ABSTRAK
Tujuan penelitian ini adalah untuk mengetahui apakah ada pengaruh senam lansia terhadap penurunan hipertensi pada lanjut usia yang mengalami hipertensi di Posbindu Cempaka Permai Kota Bengkulu. Penelitian ini menggunakan metode pre-eksperimen. Hasil penelitian menunjukan pada kelompok intervensi rata-rata penurunan tekanan darah sistolik 21,00 $\mathrm{mmHg}$, dari 171,50 $\mathrm{mmHg}$ menjadi $150,50 \mathrm{mmHg}$, sedangkan ratarata penurunan tekanan darah diastolik $13,00 \mathrm{mmHg}$, dari $103,00 \mathrm{mmHg}$ menjadi 90,00 mmHg. Berdasarkan hasil uji t-dependent, diperoleh (nilai $\mathrm{p}=0,000)$ untuk hasil sistolik dan untuk hasil diastolik (nilai $\mathrm{p}=0,000$ ). Simpulan, ada pengaruh senam lansia terhadap penurunan tekanan darah sebelum dan sesudah dilakukan senam lansia pada lanjut usia yang mengalami hipertensi di Posbindu Cempaka Permai Kota Bengkulu.
\end{abstract}

Kata Kunci : Hipertensi, Senam Lansia, Tekanan Darah

\section{ABSTRACT}

The purpose of this study was to determine whether there is an influence of elderly exercise on decreasing hypertension in elderly who experience hypertension in Posbindu Cempaka Permai Bengkulu City. This study uses a pre-experimental method. The results showed in the intervention group, the average reduction in systolic blood pressure was $21.00 \mathrm{mmHg}$, from $171.50 \mathrm{mmHg}$ to $150.50 \mathrm{mmHg}$. In contrast, the average reduction in diastolic blood pressure was $13.00 \mathrm{mmHg}$, from $103.00 \mathrm{mmHg}$ to 90, $00 \mathrm{mmHg}$. Based on the $t$-dependent test results, obtained ( $p$-value $=0,000)$ for systolic results and for diastolic results ( $p$-value $=0,000)$. In conclusion, there is the influence of elderly exercise on decreasing blood pressure before and after the elderly's exercise in hypertensive elderly in Posbindu Cempaka Permai Bengkulu City.

Keywords: Hypertension, Elderly Gymnastics, Blood Pressure

\section{PENDAHULUAN}

Pembangunan kesehatan menurut undang-undang tahun 2009 tentang kesehatan bertujuan untuk meningkatkan kesadaran, kemauan dan kemampuan hidup sehat bagi setiap individu agar terwujudnya derajat kesehatan bagi masyarakat yang setinggitingginya, sebagai wujud pembangunan sumber daya manusia yang produktif secara sosial dan ekonomis. Salah satu untuk mencapai tujuan pembangunan kesehatan tersebut setiap individu berkewajiban berperilaku hidup sehat. Pada saat ini telah terjadi perubahan hidup sehat atau gaya hidup seseorang, sehingga berdampak pada pergeseran 
pola penyakit di mana beban penyakit tidak lagi didominasi oleh penyakit menular, tapi juga penyakit tidak menular seperti hipertensi (Kemenkes RI, 2016).

Jumlah penderita hipertensi setiap tahun di seluruh dunia terus meningkat. Pada tahun 2012 Cardiovascular Disease (CVD) membunuh 17,5 juta orang setara dengan setiap 3 dari 10 kematian, dari 17 juta kematian ini dalam setahun lebih dari 9,4 juta disebabkan oleh komplikasi pada hipertensi yang juga sering disebut peningkatan tekanan darah tinggi (IFPMA, 2016). Kawasan Asia Tenggara termasuk Indonesia, dilaporkan bahwa 49,7\% penyebab kematian adalah akibat penyakit tidak menular, salah satu di antaranya adalah hipertensi (Irawan, 2017; Sartika et al., 2018).

Prevalensi ini diprediksi akan terus meningkat sebanyak 29\% pada tahun 2025. Terdapat satu miliar orang di dunia menderita hipertensi dengan tekanan darah sistolik $\geq 140 \mathrm{mmHg}$ dan tekanan darah diastolik $\geq 90 \mathrm{mmHg}$, dari $2 / 3$ diantaranya berada di negara berkembang yang berpenghasilan rendah sampai sedang (WHO, 2015). Urbanisasi yang cepat, gaya hidup, junkfood, dan stress merupakan faktor risiko yang bertanggung jawab untuk terjadinya peningkatan prevalensi hipertensi (Andri et al., 2018; Garg et al., 2013; Padila, 2013).

Menurut Joint National Committee on Prevention, Detection, Evaluation, and Treatment on High Blood Pressure VII (JNCVII), hampir 1 milyar orang menderita hipertensi di dunia. Menurut laporan Badan Kesehatan Dunia atau WHO, hipertensi merupakan penyebab nomor 1 kematian di dunia dan dan diperkirakan, jumlah penderita hipertensi akan terus meningkat seiring dengan jumlah penduduk yang membesar. Hipertensi di Indonesia pada usia lebih dari 18 tahun sebesar 34,1\% dan tertinggi di Kalimantan Selatan sebesar 44,1\%. Prevalensi hipertensi pada umur 18 tahun ke atas di Provinsi NTB yakni mencapai 24,3\% (Riskesdas, 2018).

Hasil penelitian Sumartini et al., (2019) menunjukkan bahwa rata-rata tekanan darah sistolik sebelum dilakukan senam hipertensi lansia yaitu $151,80 \mathrm{mmHg}$, rata-rata tekanan darah diastolik yaitu $94,73 \mathrm{mmHg}$. Sebagian besar responden masuk dalam klasifikasi hipertensi stadium 1 sebanyak 23 orang. Rata-rata tekanan darah sistolik sesudah dilakukan senam hipertensi lansia yaitu $137,13 \mathrm{mmHg}$, rata-rata tekanan darah diastolik yaitu 90,27 mmHg. Yang terbanyak rmasuk dalam klasifikasi pre hipertensi sebanyak 22 orang. Berdasarkan hasil uji menggunakan paired sampel t test diperoleh $p=0,000<\alpha=0,05$. Kesimpulan pada penelitian ini adalah ada pengaruh yang signifikan senam hipertensi lansia terhadap tekanan darah lansia dengan hipertensi di wilayah kerja Puskesmas Cakranegara Kelurahan Turida Tahun 2019.

Sejalan dengan penelitian Rasiman, Ansyah (2020) Hasil penelitian ini menunjukan, dari 18 lansia yaitu untuk tekanan darah sistolik sebelum senam dengan nilai Mean $=157,8 \mathrm{mmHg}$ dan sesudah senam dengan nilai Mean $=125 \mathrm{mmHg}$ dan untuk tekanan darah diastolik sebelum senam dengan nilai Mean $=106,11 \mathrm{mmHg}$ dan sesudah senam dengan nilai Mean $=75 \mathrm{mmHg}$ dengan nilai $p$-value pada sistolik 0,000 dan diastolik 0,000 ( $p$-value $\leq 0,05)$. Ada pengaruh senam lansia terhadap perubahan tekanan darah pada lansia hipertensi di Desa Kinapasan Kabupaten Tolitoli.

Penelitian Anwari et al., (2018) menunjukkan bahwa tekanan darah sebelum pemberian intervensi sebagian besar adalah prehypertension $(87,5 \%)$, tekanan darah setelah pemberian intervensi senam hipertensi sebagian besar adalah normal (87,5\%), dan terdapat pengaruh senam anti hipertensi terhadap tekanan darah lansia di Desa Kemuningsari Lor Kecamatan Panti Kabupaten Jember (p-value = 0,001). 
Hasil penelitian Yantina \& Saputri (2019) menunjukkan bahwa ada pengaruh senam lansia terhadap penurunan tekanan darah pada wanita lansia dengan hipertensi di wilayah kerja Puskesmas Banjarsari tahun 2018 dengan nilai $\mathrm{p}$ value untuk sistolik $\mathrm{p}$ value: 0,002 ) maupun diastolic ( $\mathrm{p}$ value: 0,004 )

Penurunan tekanan darah terjadi karena pembuluh darah mengalami pelebaran dan relaksasi (Padila, 2012). Lama-kelamaan, latihan olahraga dapat melemaskan pembuluh darah, sehingga tekanan darah menurun, sama halnya dengan melebarnya pipa air akan menurunkan tekanan air. Penurunan tekanan darah juga dapat terjadi akibat aktivitas memompa jantung berkurang. Otot jantung pada orang yang rutin berolahraga sangat kuat, maka otot jantung pada individu tersebut berkontraksi lebih sedikit daripada otot jantung individu yang jarang berolahraga. Senam juga menstimulasi pengeluaran hormon endorfin. Hormon ini dapat berfungsi sebagai obat penenang alami yang diproduksi otak yang melahirkan rasa nyaman dan meningkatkan kadar endorphin dalam tubuh untuk mengurangi tekanan darah tinggi (Yantina \& Saputri, 2019).

\section{METODE PENELITIAN}

Penelitian ini menggunakan jenis penelitian kuantitatif dengan metode experimen (pre experimen design) menggunakan rancangan one grup pretest-post test design.

Populasi penelitian ini adalah sebanyak 20 orang usia lanjut yang berumur 60 tahun ke atas di Posbindu Cempaka Permai Kota Bengkulu yang mengalami hipertensi. Teknik pengambilan sampel non probabilistik dengan menggunakan purposive sampling dengan kriteria lanjut usia yang berumur 60 tahun ke atas, tidak menggunakan obat penurun tekanan darah, tidak mengalami gangguan fisik dan dapat melihat serta mendengar.

Intervensi pada satu kelompok perlakuan diberikan pengukuran 15 menit sebelum dilakukan intervensi senam lansia dan di ukur kembali setelah dilakukan intervensi senam lansia setelah 30 menit. Penelitian di lakukan selama 3x dalam satu minggu dan pengukuran yang di ambil adalah pertemuan ke 3 .

Teknik analisa data menggunakan analisa univariat dan analisa bivariat, dimana analisa univariat disajikan dalam tabel distribusikan ferkuensi, ukuran tensi, sentral atau grafik. Sedangkan analisa bivariat menggunakan menggunakan uji statistik paired sample $t$ test karena membandingkan data yang berasal dari kelompok data yang berpasangan. Dengan tingkat kepercayaan $95 \%$ atau $\alpha=0,05$.

\section{HASIL PENELITIAN Analisa Univariat}

Tabel. 1

Tekanan Darah Sistolik Sebelum dan Sesudah Senam Lansia

\begin{tabular}{ccc}
\hline Tekanan Darah Sistolik & Frekuensi & Persentase \\
\hline Sebelum Intervensi & 0 & $0 \%$ \\
Normal & 20 & $100 \%$ \\
Tinggi & & \\
Setelah Intervensi & 14 & $70,0 \%$ \\
Normal & 6 & $30,0 \%$ \\
Tinggi & & \\
\hline
\end{tabular}


Hasil penelitian menunjukan bahwa sebelum diberikan intervensi seluruh responden memiliki tekanan darah sistolik yang tinggi yaitu 20 orang (100\%). Setelah dilakukan terapi senam lansia sebahian besar tekanan darah sistolik responden normal yaitu 14 orang $(70 \%)$.

Tabel. 2

Tekanan Darah Diastolik Sebelum dan Sesudah Senam Lansia

\begin{tabular}{ccc}
\hline Tekanan Darah Diastolik & Frekuensi & Persentase \\
\hline Sebelum Intervensi & 0 & $0 \%$ \\
Normal & 20 & $100 \%$ \\
Tinggi & & \\
Setelah Intervensi & 14 & $70,0 \%$ \\
Normal & 6 & $30,0 \%$ \\
Tinggi &
\end{tabular}

Hasil menunjukan bahwa sebelum diberikan intervensi seluruh responden memiliki tekanan darah diastolik yang tinggi yaitu 20 orang (100\%). Setelah dilakukan terapi senam lansia sebahian besar tekanan darah sistolik responden normal yaitu 14 orang $(70 \%)$.

\section{Analisa Bivariat}

Tabel. 3

Analisa Bivariat Tekanan Darah Sistolik dan Diastolik Sebelum dan Setelah Dilakukan Senam Lansia

\begin{tabular}{cccccc}
\hline Tekanan Darah & Mean & N & Std. Devisation & $\begin{array}{c}\text { Standar Error } \\
\text { Mean }\end{array}$ & P Value \\
\hline Sistolik Pre & 171,50 & 20 & 8,127 & 1,817 & 0.000 \\
\hline Sistolik Post & 150,50 & 20 & 7,592 & 1,698 & \\
\hline Diastolik Pre & 103.00 & 20 & 4.702 & 1.051 & 0.000 \\
\hline Diastolik Post & 90.00 & 20 & 10.260 & 2.294 & \\
\hline
\end{tabular}

Rata-rata tekanan darah sistolik pada pengukuran pertama pada pertemuan ke 3 dalam satu minggu, 15 menit sebelum di lakaukan senam lansia adalah 171,50 $\mathrm{mmHg}$ dengan standar devisiasi 8,127. Kemudian setelah di lakukan pengukuran kembali 30 menit setelah melakukan senam lansia didapat rata-rata tekenan darah $150,50 \mathrm{mmHg}$ dengan standar devisiasi 7,592 Dan rata-rata tekanan darah diastolik pada pengukuran pertemuan ke 3 dalam satu minggu 15 menit, sebelum senam lansia di lakukan adalah 103,00 mmHg dengan standar devisiasi 4,720. Kemudian setelah dilakukan pengukuran kembali 30 menit setelah melekukan senem lansia didapatkan hasil rata-rata tekenan darah 90,00 mmHg dengan standar deviasi 10,260. 


\section{PEMBAHASAN}

\section{Pengaruh Senam Lansia terhadap Penurunan Tekanan Darah Sistolik pada Lansia yang Mengalami Hipertensi}

Berdasarkan hasil setelah penelitian didapatkan ada pengaruh senam lansia terhadap penurunan tekanan darah sistolik pada lansia yang mengalami Hipertensi di Posbindu Cempaka Permai Kota Bengkulu dengan (P Value 0,000).

Penelitian ini sejalan dengan penelitian yang dilakukan Yuliani pada tahun 2018 yang menyatakan bahwa ada pengaruh senam lansia dengan penurunan darah sistol. Senam lansia membawa pengaruh yang baik terhadap tekanan darah pada lansia yang hipertensi.

Hasil penelitian ini sejalan dengan penelitian yang dilakukan dengan Liza \& Wijaya (2015) kegiatan dilakukan selama empat minggu pada 15 orang lansia dengan hipertensi ringan sampai sedang, dari 15 responden melaksanakan senam hipertensi lansia selama $1 \mathrm{x}$ seminggu dengan durasi \pm 30 menit. Sebelum melakukan senam hipertensi lansia rata-rata tekanan darah sistolik lansia hipertensi adalah 145,33 $\mathrm{mmHg}$, rata-rata tekanan darah diastolik adalah $88,00 \mathrm{mmHg}$. Setelah melakukan senam hipertensi lansia sebagian besar responden mempunyai tekanan darah pre hipertensi dimana rata-rata tekanan darah sistolik adalah $137,33 \mathrm{mmHg}$, rata-rata tekanan darah diastolik adalah $82,00 \mathrm{mmHg}$.

Sejalan dengan penelitian yang dilakukan Izhar (2017) dimana hasil penelitiannya menunjukkan ada pengaruh senam lansia terhadap tekanan darah. Terjadi penurunan rata-rata tekanan darah sistole sebelum dilakukan senam $153,47 \mathrm{mmHg}$ menjadi 145,37 $\mathrm{mmHg}$ setelah diberikan senam lansia.

Hipertensi banyak dialami oleh lansia disebabkan oleh faktor usia, memiliki riwayat hipertensi, keturunan, jenis kelamin dan faktor kebudayaan. Hal ini disebabkan semakin tua umur seseorang maka pengaturan metabolisme zat kapurnya (kalsium) terganggu. Hal ini menyebabkan banyaknya zat kapur yang beredar bersama aliran darah, akibatnya darah menjadi padat dan tekanan darahpun meningkat (Izhar, 2017).

Selain itu seiring dengan terjadi proses penuaan pada lansia, maka terjadi kemunduran secara fisiologis pada lansia yang menyebabkan arteri besar kehilangan kelenturannya dan menjadi kaku, tidak dapat mengembang pada saat jantung memompa darah melalui arteri tersebut. Karena itu darah di setiap denyut jantung di paksa melewati pembuluh yang sempit dari pada biasanya sehingga menyebabkan naiknya tekanan darah. Inilah yang terjadi pada usia lanjut, dinding arterinya telah menebal dan kaku karena arteriosklerosis (Izhar, 2017).

Wanita menopause memiliki tekanan darah yang lebih tinggi. Hal ini menunjukkan bahwa hormon pada ovarium dapat memodulasi tekanan darah. Dilaporkan bahwa tekanan darah sistolik dan diastolik berkaitan erat dengan usia menopause. Berdasarkan riset yang dilakukan oleh Megan Coylewright dan koleganya menemukan bahwa wanita dalam masa menopause lebih tinggi tekanan darahnya ketimbang wanita pre-menopause. Hal dihubungkan dengan pengurangan pada estradiol dan penurunan perbandingan rasio estrogen dan testosteron yang mengakibatkan disfungsi endothelial dan menambah BMI yang menyebabkan kenaikan pada aktivasi saraf simpatetik. Aktivasi saraf simpatetik ini akan mengeluarkan stimulan renin dan angiotensin II. Kenaikan angiotensin and endhotelin dapat menyebabkan stres oksidatif yang berujung pada hipertensi atau darah tinggi (Yantina \& Saputri, 2019). 
Hasil penelitian Rizki (2016) juga menunjukkan bahwa olahraga senam hipertensi lansia dengan tekanan darah khususnya pada lansia cukup efektif dalam menurunkan tekanan darah yang dilakukan 6 kali berturutturut. Senam dilakukan 3 hari selama 3 minggu dengan hasil rata-rata penurunan tekanan darah sistolik adalah $11,26 \mathrm{mmHg}$ dan rata-rata penurunan tekanan darah diastolik adalah $18,48 \mathrm{mmHg}$. Hasil penelitian ini sesuai dengan teori yang diatas. Peneliti berpendapat bahwa senam hipertensi lansia dapat menurunkan tekanan darah sistolik adalah $14,67 \mathrm{mmHg}$ dan tekanan darah diastolik adalah 4,46 $\mathrm{mmHg}$. Hasil wawancara dengan responden didapatkan mereka merasa lebih segar, bugar dan sehat setelah melakukan senam hipertensi lansia, yang dibarengi dengan menggunakan obat tradisional dan obat farmakologi diberikan 1 kali seminggu.

Menurut Tulak \& Umar (2017) hipertensi pada lansia terjadi akibat proses penuaan pada lansia yaitu terjadi kemunduran fisiologis yang menyebabkan kekuatan mesin pompa jantung berkurang serta arteri besar kehilangan kelenturannya dan menjadi kaku dan, tidak dapat mengembang pada saat jantung memompa darah melalui arteri tesebut yang mengakibatkan naiknya tekanan darah. Adanya pengaruh senam lansia terhadap penurunan tekanan darah lansia penderita hipertensi disebabkan oleh gerakan berupa senam lansia yang dilakukan oleh lansia merangsang peningkatan kekuatan pompa jantung serta merangsang vasodilatasi pembuluh darah sehingga aliran darah lancar dan terjadi penurunan tekanan darah.

Penurunan tekanan darah terjadi karena pembuluh darah mengalami pelebaran dan relaksasi. Lama-kelamaan, latihan olahraga dapat melemaskan pembuluh-pembuluh darah, sehingga tekanan darah menurun, sama halnya dengan melebarnya pipa air akan menurunkan tekanan air. Penurunan tekanan darah juga dapat terjadi akibat aktivitas memompa jantung berkurang. Otot jantung pada orang yang rutin berolahraga sangat kuat, maka otot jantung pada individu tersebut berkontraksi lebih sedikit daripada otot jantung individu yang jarang berolahraga. Senam juga menstimulasi pengeluaran hormon endorfin. Hormon ini dapat berfungsi sebagai obat penenang alami yang diproduksi otak yang melahirkan rasa nyaman dan meningkatkan kadar endorphin dalam tubuh untuk mengurangi tekanan darah tinggi (Yantina \& Saputri, 2019).

Senam terbukti dapat meningkatkan kadar endorphin empat sampai lima kali dalam darah. Sehingga, semakin banyak melakukan senam maka akan semakin tinggi pula kadar bendorphin. Ketika seseorang melakukan senam, maka bendorphin akan keluar dan ditangkap oleh reseptor di dalam hipothalamus dan sistem limbik yang berfungsi untuk mengatur emosi. Peningkatan b-endorphin terbukti berhubungan erat dengan penurunan rasa nyeri, peningkatan daya ingat, memperbaiki nafsu makan, kemampuan seksual, tekanan darah dan pernafasan. Olahraga juga dapat mengurangi tekanan darah melalui pengurangan berat badan sehingga jantung akan bekerja lebih ringan dan tekanan darah berkurang (Yantina \& Saputri, 2019).

Saat jantung berdetak, otot jantung akan berkontraksi untuk memompa darah melalui arteri ke seluruh tubuh. Kontraksi otot jantung tersebut kemudian akan menimbulkan tekanan pada arteri. Tekanan inilah yang disebut sebagai tekanan darah sistolik. Ketika kontraksi otot jantung telah berakhir, maka otot jantung pun akan menjadi rileks sehingga suplai darah ke aorta akan berhenti kirakira 1/10 detik. Pada saat inilah aorta akan kembali ke posisi semula dan tekanan darah pun menurun. Tekanan darah di dalam arteri ketika jantung sedang beristirahat/rileks (antar detak) inilah yang kemudian disebut dengan tekanan darah diastolik (Yantina \& Saputri, 2019). 


\section{Pengaruh Senam Lansia terhadap Penurunan Tekanan Darah Diastolik pada Lansia yang Mengalami Hipertensi}

Berdasarkan hasil setelah penelitian didapatkan ada pengaruh senam lansia terhadap penurunan tekanan darah distolik pada lansia yang mengalami Hipertensi di Posbindu Cempaka Permai Kota Bengkulu dengan (P Value 0,000).

Sejalan dengan penelitian yang dilakukan Izhar (2017) dimana hasil penelitiannya menunjukkan ada pengaruh senam lansia terhadap tekanan darah. Terjadi penurunan rata-rata tekanan darah diastole sebelum dilakukan senam $86,81 \mathrm{mmHg}$ menjadi 82,89 $\mathrm{mmHg}$ setelah diberikan senam lansia.

Penelitian Sianipar \& Putri (2018) Dari penelitian ini didapatkan nilai $p$ value adalah $0,000<\alpha 0,05$ yang berarti terdapat pengaruh senam hipertensi terhadap tekanan darah pada penderita hipertensi di Puskesmas Kayon Kota Palangka Raya. Sejalan dengan penelitian yang dilakukan Hutagalung \& Susilawati (2020) yang menyatakan bahwa senam lansia efektif dalam menurunkan tekanan darah pada lansia dengan nilai $\mathrm{p}$ 0,000 .

Sejalan dengan penelitian Rasiman \& Ansyah (2020) hasil penelitian ini menunjukan, dari 18 lansia yaitu untuk tekanan darah sistolik sebelum senam dengan nilai Mean $=157,8 \mathrm{mmHg}$ dan sesudah senam dengan nilai mean $=125 \mathrm{mmHg}$ dan untuk tekanan darah diastolik sebelum senam dengan nilai mean $=106,11 \mathrm{mmHg}$ dan sesudah senam dengan nilai Mean $=75 \mathrm{mmHg}$ dengan nilai $p$-value pada sistolik 0,000 dan diastolik 0,000 ( $p$-value $\leq 0,05)$. Ada pengaruh senam lansia terhadap perubahan tekanan darah pada lansia hipertensi di Desa Kinapasan Kabupaten Tolitoli.

Sejalan dengan penelitian yang dilakukan Sumartini et al., (2019) Hasil penelitian menunjukkan rata-rata tekanan darah sistolik sebelum senam hipertensi lansia 151,80 $\mathrm{mmHg}$, diastolik $94,73 \mathrm{mmHg}$ dan rata-rata tekanan darah sistolik sesudah senam hipertensi lansia 137,13 $\mathrm{mmHg}$, diastolik $90,27 \mathrm{mmHg}$. Hasil uji paired sampel t-test didapatkan $\mathrm{p}=0,000<\alpha=0,05$ ada pengaruh yang signifikan senam hipertensi lansia terhadap tekanan darah lansia dengan hipertensi.

Tujuan dilakukan senam adalah untuk meningkatkan aliran darah dan pasokan oksigen ke dalam otot-otot dan rangka yang aktif khususnya terdapat otot jantung sehingga dapat menurunkan tekanan darah. Setelah beristirahat pembuluh darah akan berdilatasi atau meregang, dan aliran darah akan turun sementara waktu, sekitar 30-120 menit kemudian akan kembali pada tekanan darah sebelum senam. Jika melakukan olahraga secara rutin dan secara terus menerus, maka pembuluh darah akan lebih elastis dan penurunan tekanan darah akan berlangsung lebih lama. Sehingga dengan melebarnya pembuluh darah, tekanan darah akan menurun setelah melakukan aktifitas olahraga (Hernawan \& Rosyid, 2017).

Penderita hipertensi yang rutin mengikut senam hipertensi dapat menurunkan tekanan darahnya, hal ini menunjukkan bahwa olah ragaa atau senam hipertensi yang teratur dapat membantu meningkatkan aliran darah dan pasokan oksigen ke dalam otot otot jantung dan dapat merilekskan pembuluh darah sehingga hipertensi dapan dikendalikan (Sianipar \& Putri, 2018).

Hasil penelitian Andri et al., (2019); Rizki (2016) juga menunjukkan bahwa olahraga senam hipertensi lansia dengan tekanan darah khususnya pada lansia cukup efektif dalam menurunkan tekanan darah yang dilakukan 6 kali berturutturut. Senam dilakukan 3 hari selama 3 minggu dengan hasil rata-rata penurunan tekanan darah sistolik adalah $11,26 \mathrm{mmHg}$ dan rata-rata penurunan tekanan darah diastolik adalah $18,48 \mathrm{mmHg}$. Hasil penelitian ini sesuai dengan teori yang diatas. Peneliti berpendapat 
bahwa senam hipertensi lansia dapat menurunkan tekanan darah sistolik adalah 14,67 $\mathrm{mmHg}$ dan tekanan darah diastolik adalah 4,46 $\mathrm{mmHg}$.

Olah raga dan latihan pergerakan secara teratur seperti senam lansia secara teratur dapat menanggulangi masalah akibat perubahan fungsi tubuh dan olahraga sangat berperan penting dalam pengobatan tekanan darah tinggi. Bukti-bukti yang ada menunjukkan bahwa latihan dan olahraga pada usia lanjut dapat mencegah atau melambatkan kehilangan fungsi tubuh tersebut, bahkan latihan yang teratur dapat menurunkan tekanan darah 5-10 mmHg baik pada tekanan sistole maupun diastole, olahraga yang tepat untuk lansia adalah senam lansia. Dengan adanya latihan fisik atau senam lansia yang teratur dan terus menerus maka katup-katup jantung yang tadinya mengalami sklerosis dan penebalan berangsur kembali normal, miokard tidak terjadi kekakuan lagi, adanya kontraksi otot jantung, isi sekuncup dan curah jantung tidak lagi mengalami peningkatan. Hal ini akan mengakibatkan tekanan darah tidak lagi meningkat atau mengalami penurunan tekanan darah (Izhar, 2017).

Selanjutnya, Izhar juga berasumsi bahwa senam lansia sangat bermanfaat terhadap penurunan tekanan darah pada lansia penderita hipertensi. Adapun manfaat senam lansia tersebut adalah untuk memperlancar peredaran darah, meningkatkan daya tahan jantung, paru dan pembuluh darah, meningkatkan daya tahan dan kekuatan otot, mengurangi resiko terjadinya penyakit degeneratif seperti tekanan darah tinggi, jantung koroner, diabetes melitus.

\section{SIMPULAN}

Ada pengaruh antara pemberian senam lansia terhadap penurunan tekanan darah sistolik dan diastolik yang mengalami hipertensi. Ada perbedaan tekanan darah sebelum dan sesudah di berikan perlakuan senam lansia pada hipertensi sistolik dan diastolik.

\section{SARAN}

Bagi institusi di POSBINDU yang di gerakan oleh Puskesmas Lingkar Barat Kota Bengkulu dapat menjadikan senam lansia menjadi 3 kali dalam seminggu dalam pemberian pelayanan kesehatan untuk dapat menurunkan tekanan darah pada lanjut usia yang mengalami hipertensi sistolik dan diastolik dan tetap memperhatikan penyakitpenyakit lain yang menyertai. Keluarga agar dapat mendukung kegiatan senam lansia 3 kali dalam seminggu terhadap lansia yang mengalami Hipertensi.

\section{DAFTAR PUSTAKA}

Andri, J., Karmila, R., Padila, P., Harsismanto, J., \& Sartika, A. (2019). Pengaruh Terapi Aktivitas Senam Ergonomis terhadap Peningkatan Kemampuan Fungsional Lansia. Journal of Telenursing, 1(2), 304-313. https://doi.org/https://doi.org/10.31539/joting.v1i2.933

Andri, J., Waluyo, A., Jumaiyah, W., \& Nastashia, D. (2018). Efektivitas Isometric Handgrip Exercise dan Slow Deep Breathing Exercise terhadap Perubahan Tekanan Darah pada Penderita Hipertensi. Jurnal Keperawatan Silampari, 2(1), 371-384. https://doi.org/10.31539/jks.v2i1.382

Anwari, M., Vidyawati, R., Salamah, R., Refani, M., Winingsih, N., Yoga, D., Inna, R., \& Susanto, T. (2018). Pengaruh Senam Anti Hipertensi Lansia terhadap Penurunan Tekanan Darah Lansia di Desa Kemuningsari Lor Kecamatan Panti Kabupaten Jember. The Indonesian Journal of Health Science, 161-164. https://doi.org/10.32528/ijhs.v0i0.1541 
Garg, R., Malhotra, V., Dhar, U., \& Tripathi, Y. (2013). The Isometric Handgrip Exercise as a Test for Unmasking Hypertension in the Offsprings of Hypertensive Parents. Journal of Clinical and Diagnostic Research, 7(6), 996-999. https://doi.org/10.7860/JCDR/2013/5094.3043

Hernawan, T., \& Rosyid, F. N. (2017). Pengaruh Senam Hipertensi Lansia terhadap Penurunan Tekanan Darah Lansia dengan Hipertensi di Panti Werdha Dhara Bakti Kelurahan Pajang Surakarta. Jurnal Kesehatan, 10(1)

Hutagalung, A. M., \& Susilawati, E. (2020). Efektifitas Senam Lansia terhadap Penurunan Tekanan Darah kepada Lansia yang Mengalami Hipertensi di Puskesmas Pancur Batu Deli Serdang Tahun 2019. Poltekkes Kemenkes Medan. http://poltekkes.aplikasi-akademik.com/xmlui/handle/123456789/2055

IFPMA. (2016). Hypertension: Putting the Pressure on the Silent Killer. https://www.ifpma.org/Resource-Centre/Hypertension-Putting-The-Pressure-OnThe-Silent-Killer/

Irawan, O. (2017). Pengaruh Terapi Rendam Air Hangat pada Kaki Sambil Mendengarkan Musik Klasik terhadap Penurunan Tekanan Darah pada Penderita Hipertensi di Wilayah Kerja Puskesmas Basuki Rahmad Kota Bengkulu. Poltekkes Kemenkes Bengkulu

Izhar, M. D. (2017). Pengaruh Senam Lansia terhadap Tekanan Darah di Panti Sosial Tresna Werdha Budi Luhur Jambi. Jurnal Ilmiah Universitas Batanghari Jambi, 17(1), 204-210. https://doi.org/10.33087/jiubj.v17i1.116

Kemenkes RI. (2016). Undang-Undang Nomor 36 Tahun 2009 tentang Kesehatan

Liza, M., \& Wijaya, K. (2015). Pelaksanaan Senam Jantung Sehat untuk Menurunkan Tekanan Darah pada Pasien Hipertensi di Panti Sosial Tresna Wherda Kasih Sayang Ibu Batu Sangkar. Jurnal Stikes Yarsi, 1

Padila, P. (2012). Buku Ajar Keperawatan Medikal Bedah. Yogyakarta: Nuha Medika

Padila, P. (2013). Keperawatan Gerontik. Yogyakarta: Nuha Medika

Rasiman, N. B., \& Ansyah, A. (2020). Pengaruh Senam Lansia terhadap Perubahan Tekanan Darah pada Lansia. Pustaka Katulistiwa, 1(1), 6-11

Riskesdas. (2018). Hasil Utama Riset Kesehatan Dasar. Kementrian Kesehatan Republik Indonesia, 1-100. https://doi.org/1 Desember 2013

Rizki, M. (2016). Hubungan Tingkat Pendidikan dan Aktivitas Fisik dengan Fungsi Kognitif pada Lansia di Kelurahan Darat. Universitas Sumatera Utara

Sartika, A., Wardi, A., \& Sofiani, Y. (2018). Perbedaan Efektivitas Progressive Muscle Relaxation (PMR) dengan Slow Deep Breathing Exercise (SDBE) terhadap Tekanan Darah Penderita Hipertensi. Jurnal Keperawatan Silampari, 2(1), 356370. https://doi.org/https://doi.org/10.31539/jks.v2i1.380

Sianipar, S. S., \& Putri, D. K. F. (2018). Pengaruh Senam Hipertensi terhadap Tekanan Darah Penderita Hipertensi di Puskesmas Kayon Kota Palangka Raya. Dinamika Kesehatan, 9(2), 558-566

Sumartini, N. P., Zulkifli, Z., \& Adithya, M. A. P. (2019). Pengaruh Senam Hipertensi Lansia terhadap Tekanan Darah Lansia dengan Hipertensi di Wilayah Kerja Puskesmas Cakranegara Kelurahan Turida Tahun 2019. Jurnal Keperawatan Terpadu, 1(2), 47-55

Tulak, T., \& Umar, U. (2017). Pengaruh Senam Lansia terhadap Penurunan Tekanan Darah Lansia Penderita Hipertensi di Puskesmas Wara Palopo 
WHO (World Health Organization). (2015). Prevalence of raised blood pressure. http:/gamapserver.who.int/gho/interactive_charts/ncd/risk_factors/blood_pressure _prevalence/atlas.html

Yantina, Y., \& Saputri, A. (2019). Pengaruh Senam Lansia terhadap Tekanan Darah pada Wanita Lansia dengan Hipertensi di Wilayah Kerja Puskesmas Banjarsari Metro Utara Tahun 2018. Jurnal Farmasi Malahayati, 2(1), 112-121 